\title{
Kontrak Berjangka Komoditas Emas Sebagai Instrumen Transaksi Derivatif dalam Kajian Hukum Ekonomi Syariah
}

\author{
Surya Muhammad Gunarsa \\ Fakultas Hukum Universitas Padjajaran \\ suryamhmmd@icloud.com
}

\begin{abstract}
Gold futures contract are one form of business development and become a part of derivative instrument. Futures contract is one of derivative instrument which its value based on underlying asset's. At the beginning, the futures contracts were traded with hedging motive, but now they are traded with speculative motive also to get more profit from price fluctuatuations. Indonesia is a country with muslims as a majority, analysis from a sharia point of view is needed in order to accomodate business advancement so that the Indonesian people can live all the joints of life based on Islamic Shari'a in this modern era. In the sharia concept the clarity of goods both in quality and quantity and delivery of goods becomes essential in a transaction, in derivative transactions this is not the main thing so that there are prohibited transaction elements, namely maysir and gharar, to accommodate those institutions authorized in Indonesia is related to halal or illegitimate transactions, namely the Majelis Ulama Indonesia issues a fatwa that provides a certain mechanism so that a derivative transaction becomes a transaction that allowed by Islamic sharia perspective.
\end{abstract}

Keywords: gold futures contract; derivative instrument; shari'a economic perspective 


\begin{abstract}
Abstrak
Kontrak berjangka emas merupakan salah satu bentuk dari perkembangan dalam jual-beli di dunia dan merupakan bagian dari instrumen derivatif. Instrumen derivatif merupakan nilai turunan dari underlying asset. Pada mulanya perdagangan berjangka digunakan untuk melakukan perlindungan nilai (hedge), namun seiring berjalannya waktu kontrak berjangka emas diperdagangkan dengan motif spekulatif guna mendapat keuntungan dari fluktuasi harga. Indonesia merupakan negara dengan mayoritas warga beragama Islam, dan karenanya perkembangan-perkembangan dalam persoalan kemasyarakatan termasuk jual-beli perlu adanya analisis dari sudut padang syariah, guna mengakomodasi perubahan zaman dan masyarakat dapat menjalani segala sendi kehidupan berdasarkan syariat Islam. Dalam konsep syariah, kejelasan barang baik secara kualitas maupun kuantitas dan penyerahan barang menjadi hal yang esensial dalam suatu transaksi. Dalam transaksi derivatif, hal tersebut bukan menjadi hal yang utama sehingga di dalamnya terdapat unsur transaksi yang dilarang yaitu maysir dan gharar. Untuk mengakomodasi hal tersebut, institusi berwenang di Indonesia terkait halal atau haramnya suatu transaksi yaitu Majelis Ulama Indonesia mengeluarkan fatwa yang memberikan mekanisme tertentu agar suatu transaksi derivatif menjadi suatu transaksi yang tidak bertentangan dengan syariat Islam.
\end{abstract}

Kata Kunci: kontrak berjangka emas; transaksi derivatif; pandangan ekonomi syariah

\title{
A. Pendahuluan
}

Artikel ini membahas pandangan hukum ekonomi syariah terhadap transaksi berjangka emas sebagai barang komoditi, yang merupakan salah satu jenis perkembangan jual-beli. Dalam artikel ini, bentuk transaksi berjangka emas akan ditelaah dari perspektif hukum ekonomi syariah, baik itu berkenaan dengan rukun dan syaratnya, maupun akibat hukumnya. Dalam Islam telah diatur secara tegas mengenai rukun, syarat, maupun bentuk dari jual-beli, dan karenanya relevan untuk mengaitkannya dengan bentuk jual-beli terkini.

Jual-beli sendiri dari segi istilah berarti penukaran antara barang dengan barang, atau barang dengan uang. Di dalamnya terjadi per- 
pindahan hak milik atas suatu objek jual-beli dari satu pihak ke pihak yang lain atas dasar sukarela. Objek jual-beli merupakan hal yang esensial pada suatu transaksi jual-beli. Dalam Islam, objek jual-beli dapat disebut dengan ma'qud 'alaih. Objek dalam jual-beli dapat berupa barang maupun manfaat, dengan syarat tukar-menukar yang berlaku selamanya atau tidak sementara, sehingga sewa menyewa (ijarah) tidak termasuk kedalam jual-beli karena pemanfaatannya bersifat sementara. ${ }^{1}$

Akadjual-belimerupakanakadyangsudahumumpenggunaannya di masyarakat karena untuk memenuhi kebutuhannya. Dalam Islam, jual-beli pada dasarnya tidak dilarang. Namun demikian, Islam mengatur mengenai apa saja yang berkaitan dengan jual-beli agar masyarakat tidak terjebak dalam transaksi yang merugikan dan dilarang oleh syari'at.

Objek dalam jual-beli dapat dikelompokkan menjadi tiga, yaitu jual-beli benda yang terlihat, jual-beli benda yang disebutkan dalam janji atau salam, dan jual-beli benda yang tidak ada. ${ }^{2}$ Dalam perkembangannya terdapat pergeseran bahkan perubahan karena kehadiran teknologi internet mengubah berbagai hal, salah satunya adalah mempermudah masyarakat untuk melakukan transaksi jualbeli.

Salah satu pekembangan jual-beli adalah transaksi derivatif yang merupakan perjanjian penukaran pembayaran yang nilainya diturunkan atau berasal dari produk yang menjadi "acuan pokok" atau dapat disebut produk turunan. ${ }^{3}$ Fungsi dari transaksi derivatif adalah untuk melindungi nilai (mengalihkan atau mengambil resiko) yang tergantung pada posisinya sebagai spekulator atau hedger. Jenis utama dalam transaksi derivatif adalah futures (kontrak berjangka), forward (kontrak serah), opsi, dan swap.

1 Ahmad Wardi Muslich, Fiqh Muamalat: Akad Jual-beli (Kifayatul al-Akhyar Juz I) (Surabaya: Darul Ilmi, 2010), hlm. 173.

2 Taqiyyudin Abubakar, Kifayatul Akhyar fii Halli Ghayatil Ikhtisar, terj. Syarifudin Anwar dan Misbah Mustofa (Surabaya: CV Bina Iman, 1995), hlm. 392.

3 Dimyati, “Transaksi Derivatif dalam Perspektif Ekonomi Syariah”, Irtifaq, 2, 1 (2015): 98-115. 
Dalam transaksi derivatif, produk-produk yang menjadi acuan adalah berbagai jenis aset yang di antaranya adalah komoditi, suku bunga, valuta asing, dan suku bunga. Transaksi ini dapat dikategorikan sebagai transaksi yang tidak riil, atau dengan kata lain transaksi finansial karena sebenarnya tidak ada hubungannya barang secara fisik. Salah satu produk dari pasar derivatif adalah emas berjangka. Dalam ajaran Islam dijelaskan prinsip muamalah yaitu prinsip dalam jualbeli yang disetarakan dengan emas (dinar) dan perak (dirham) harus dilakukan dengan sama jenis agar tidak menyentuh koridor ribawi.

Transaksi emas berjangka melalui pasar derivatif pada konsepnya merupakan transaksi yang penyerahannya dapat dilakukan di masa yang akan datang, namun kenyataannya transaksi emas berjangka digunakan menjadi sarana spekulatif karena para pihak menggunakan perubahan besaran harga yang menunjukkan fluktuasi dalam periode waktu tertentu (volatilitas) dari harga dasar emas. Kontrak derivatif emas yang dibuat diselesaikan sebelum waktunya (jatuh tempo) sehingga kewajiban untuk melakukan penyerahan menjadi gugur.

Dalam hukum Islam, persoalan terkait transaksi berjangka emas dapat dikategorikan sebagai masalah-masalah modern yang sulit dikaitkan dengan ketentuan hukum yang sudah ada sebelumnya, sehingga berdampak pada status hukumnya yang tergolong pada ijtihadiyyah. Kategori ini adalah kategori masalah hukum yang tidak memiliki nash hukum yang pasti, oleh karena nash hukum dalam al-Quran dan sunnah Nabi sudah selesai, maka masalah-masalah kontemporer harus diberikan jawaban melalui ijtihad.

Artikel ini setelah bagian ini menjelaskan terlebih dahulu transaksi derivatif dan perdagangan berjangka komoditi. Uraian ini diperlukan untuk mengetahui prinsip dan skema yang berlaku dalam transaksi derivatif dan perdagangan berjangka komoditi. Pada bagian berikutnya, transaksi derivatif dan perdagangan berjangka komoditas emas ditelaah dari sudut pandang hukum ekonomi syariah. Oleh karenanya, sumber hukum Islam, yaitu Al-Qur'an, Hadits Nabi, dan Ijma’ Ulama menjadi bahan primer dalam menjelaskan kebolehan atau tidaknya transaksi derivitaif. 


\section{B. Transaksi Derivatif dan Perdagangan Berjangka Komoditi}

Transaksi derivatif merupakan suatu jenis transaksi disebut dengan hybrid investment atau transaksi turunan. ${ }^{4}$ Pada dasarnya transaksi ini digunakan untuk mengelola suatu investasi, namun seiring berjalannya waktu transaksi derivatif tidak menggambarkan transaksi pada sektor riil khususnya pada pasar saham dan valuta asing. Transaksi derivatif dapat dilakukan dengan bentuk transaksi forward, futures, swap maupun dengan bentuk option. Dalam pengertian yang lebih spesifik, derivatif merupakan kontrak finansial yang dilakukan minimal dua pihak untuk menjual atau membeli aset atau komoditas yang dijadikan objek dalam perjanjian pada waktu dan harga yang disepakati. Adapun nilai-nilai di masa mendatang dari objek tersebut sangatlah dipengaruhi oleh instrumen induknya yang ada di spot market. $^{5}$

Transaksi derivatif yang ada di bursa keuangan adalah financial derivative yang merupakan instrumen derivatif yang didasari oleh instrumen keuangan yang dapat berupa saham, obligasi, valuta asing, komoditas dan instrumen keuangan lainnya yang biasa digunakan oleh pelaku pasar sebagai sarana lindung nilai (hedging) atas portofolio yang dimiliki. ${ }^{6}$ Dalam Surat keputusan Bank Indonesia Nomor 28/119/KEP/DIR, transaksi derivatif didefinisikan sebagai suatu kontrak atau perjanjian pembayaran yang nilainya merupakan turunan dari instrumen yang mendasari seperti tingkat suku bunga, nilai tukar, komoditi, ekuiti, dan indeks, baik yang diikuti dengan pergerakan atau tanpa pergerakan dana atau instrumen.

Sebagaimana disebutkan sebelumnya, terdapat empat bentuk transaksi derivatif, yaitu future, forward, option, dan swap. Pertama, transaksi future atau future contract, yaitu kontrak untuk membeli

4 Virginia B. Morris \& Kenneth B. Morris, Dictionary of Financial Terms (New York: Lightbulb Press, tanpa tahun), hlm. 41.

5 Peraturan Bank Indonesia No. 7/31/PBI/2008 tentang Transaksi Derivatif.

6 Imam Buchori, “Transaksi Derivatif dalam Perspektif Hukum Islam, AlQānūn, 12, 1 (2009), hlm. 141. 
komoditi tertentu maupun surat berharga pada harga tertentu di masa depan atau dengan kata lain future contract merupakan perjanjian berupa kontrak yang dibuat pada bursa berjangka untuk membeli atau menjual suatu komoditas pada waktu yang akan datang. Dalam transaksi ini diharuskan pemegangnya untuk membeli dan menjual aset, bagaimanapun kondisi nilainya dalam selang waktu tertentu. Future contract merupakan hal yang penting karena kontrak tersebut dapat digunakan oleh manajemen keuangan untuk mengunci harga komoditi atau suku bunga dari fluktuasi harga yang tidak bisa diprediksi. Dengan mengunci harga dari komoditi atau suku bunga maka biaya-biaya yang berkaitan akan diimbangi oleh keuntungan yang dihasilkan dengan membuat kontrak future. ${ }^{\top}$

Kedua, transaksi forward, yaitu transaksi perdagangan yang dilakukan pada suatu waktu namun penyerahan barangnya pada masa yang akan datang. Dalam transaksi ini, baik harga, jumlah barang, waktu dan tempat penyerahan telah ditetapkan dalam kontrak, namun uang maupun barang diserahkan pada waktu yang telah disepakati. Dalam transaksi ini, penentuan harga ditetapkan oleh kekuatan dan penawaran terhadap komoditas barang untuk waktu yang berbeda-beda. ${ }^{8}$ Forward contract berbeda dengan future, yaitu dalam penyerahan barang. pada kontrak forward, penyerahan barang berlangsung pada jangka waktu satu sampai enam bulan ke depan, sedangkan pada kontrak future ada pada enam bulan lebih. ${ }^{9}$

Ketiga, transaksi option, merupakan hak yang didasarkan pada suatu perjanjian untuk membeli atau menjual suatu instrumen pada tingkat harga tertentu yang ditetapkan sebelumnya guna penyerahan di masa depan. ${ }^{10}$ Transaksi option adalah transaksi antara penjual dan pembeli yang masing-masing sepakat untuk menjual asetnya

7 John D. Martin, Dasar-Dasar Manjemen Keuangan, terj. Haris Munandar (Jakarta: Raja Grafindo Persada, 1994), hlm. 302.

8 Sheikh Ghazali Shaikh Abod, dkk., An Introduction to Islamic Finance (Kuala Lumpur: Quill Publishers, 1992), hlm. 318 .

9 Hamdi Abdul 'Adhim, al-Ta'amul fi Aswaq al-'Umulat al-Dawliyah (Kairo: International Institute for Islamic Thougt, 1996), hlm. 20.

10 Dian Ediana Rae, Transaksi Derivati dan Masalab Regulasi di Indonesia (Jakarta: PT Elex Media Komputindo, 2008), hlm. 61. 
ketika aset tersebut mencapai harga tertentu. Pada transaksi option terdapat dua macam pilihan, yaitu call option yang merupakan hak pembeli untuk melaksanakan atau membatalkan pilihan jual-beli, dan put option yang merupakan hak penjual untuk melaksanakan atau membatalkan opsi jual-beli berjangka. ${ }^{11}$

Keempat, transaksi swap, yaitu kontrak untuk menukarkan aliran kas yang dihitung atas suatu referensi terhadap tingkat harga atau indeks yang telah ditetapkan di awal atau telah diketahui ${ }^{12}$. Transaksi swap merupakan transaksi yang didasari suatu kontrak untuk melakukan pertukaran valas melalui pembelian secara tunai atau berjangka dengan perjanjian untuk menjual kembali secara tunai atau berjangka.

Salah satu alasan munculnya transaksi derivatif adalah untuk memenuhi kebutuhan dalam berinvestasi, investasi sendiri memiliki tujuan untuk melindungi dari resiko-resiko yang berkemungkinan terjadi dimasa datang, semakin besar investasi semakin besar pula perlindungan yang diperoleh. Transaksi derivatif dari sudut pandang investasi dapat dilihat dari sifatnya yang merupakan sarana lindung nilai akan suatu hal seperti suku bunga, nilai tukar, saham, obligasi, indeks, dan komoditas dari resiko seperti inflasi, kenaikan atau penurunan suku bunga, resiko pasar, dan lain-lain yang mengakibatkan menurunnya suatu nilai atau harga dalam dunia transaksi ekonomi. Frank J. Fafozzi berpendapat bahwa transaksi derivatif memiliki tujuan sebagai model investasi, informasi harga, fungsi spekulatif, dan sebagai sarana lindung nilai. ${ }^{13}$ Namun demikian, transaksi derivatif juga dapat membawa resiko ke level yang lebih tinggi tergantung bagaimana nasabah menggunakannya. ${ }^{14}$

Perdagangan berjangka komoditi merupakan suatu perjanjian jual-beli antara dua pihak yang menjadikan komoditi sebagai objek dalam perjanjiannya dan penyerahan dari objek perjanjian tersebut

11 Christopher Pass, Bryan Lowes, Leslie Davis, Kamus Lengkap Ekonomi, terj. Tumpal Rumapea (Jakarta: Penerbit Erlangga, 1998), hlm. 465.

12 Buchori, “Transaksi Derivatif dalam Perspektif Hukum Islam”, hlm. 141.

13 Frank J. Fafozzi, Pasar dan Lembaga Keuangan (Jakarta: Salemba Empat, 1999), hlm. 12.

14 Lani Salim, Derivatif: Option dan Varrant (Jakarta: Gramedia, 2003), hlm. 4. 
yang berupa komoditi dilakukan pada waktu yang akan datang dan harga tertentu. ${ }^{15} \mathrm{Di}$ Indonesia, perdagangan berjangka komoditi diatur dalam Undang-undang Nomor 32 tahun 1997 tentang Perdagangan Berjangka sebagaimana telah diubah dengan Undangundang Nomor 10 Tahun 2011. Dalam UU Perdaganan berjangka tersebut khususnya Pasal 1 disebutkan bahwa perdagangan berjangka komoditi adalah "segala sesuatu yang berkaitan dengan jualbeli komoditi dengan penarikan margin dan dengan penyerahan kemudian berdasarkan kontrak berjangka kontrak derivatif syariah, dan/atau kontrak derivatif lainya”.

Komoditi dalam hal ini diartikan sebagai barang, jasa, hak dan kepentingan lainnya, dan setiap derivatif lain komoditi yang dapat diperdagangkan dan menjadi subjek kontrak berjangka, kontrak derivatif syariah, dan/atau kontrak derivatif lainnya. Ketentuan mengenai komoditi tersebut secara tegas diatur dalam Pasal 1 ayat (2). Kegiatan transaksi jual-beli berjangka komoditi dilakukan pada bursa berjangka, ${ }^{16}$ sehingga transaksi berjangka komoditi sejatinya tidak dapat dipisahkan dari bursa berjangka komoditi.

Peran dari bursa berjangka komoditi adalah untuk menentukan standar dari suatu kontrak berjangka komoditi, dan bursa berjangka juga membuat suatu sistem atau mekanisme agar dapat menjamin kontrak yang dibuat oleh masing-masing pihak dapat dipenuhi. ${ }^{17} \mathrm{Hal}$ ini berarti bursa berjangka komoditi berperan menjamin bagaimana kontrak berjangka dapat terlaksana dengan baik. Kontrak berjangka sendiri adalah suatu bentuk kontrak standar untuk membeli atau menjual komoditi dengan penyelesaian kemudian sebagaimana telah ditetapkan di dalam kontrak yang diperdagangkan di dalam bursa berjangka. ${ }^{18}$ Sedangkan opsi dalam kontrak berjangka adalah kontrak yang memberikan hak kepada pembeli untuk membeli atau

15 John C. Hull, Options, Futures and Other Derivatives (New Jersey: PrenticeHall, 1997), hlm. 4.

16 Hull, Options, Futures and Other Derivatives, hlm. 4.

17 Hull, Options, Futures and Other Derivatives, hlm. 5.

18 Pasal 1 angka 5, Undang-undang Nomor 10 Tahun 2011 tentang Perubahan atas Undang-undang Nomor 32 Tahun 1997 tentang Perdagangan Berjangka Komoditi. 
menjual kontrak berjangkaatau komoditi pada tingkat harga, jumlah dan jangka waktu tertentu yang telah ditetapkan dengan membayar premi. ${ }^{19}$

Dalam perdagangan berjangka komoditi ada beberapa unsur yang mempunyai pengaruh paling signifikan, di antaranya adalah hedger, spekulator, dan arbitrator. Hedger merupakan pihak yang melakukan lindung nilai atau yang dikenal sebagai hedging dalam rangka mengelola resiko yang dilakukan dengan cara memindahkan sebagian atau semua resiko kepada pihak yang mau menerimanya, yang disebut spekulator. Hedger dapat diposisikan sebagai penjual maupun pembeli. Ketika hedger diposisikan sebagai penjual, maka ia disebut dengan short hedger, dan sebaliknya, ketika berposisi sebagai pembeli akan disebut long hedger. Senada dengan pengertian tersebut, kegiatan menjual dalam transaksi berjangka disebut dengan short hedge dan menjual adalah long hedge.

Spekulator adalah pihak yang menerima limpahan sebagian resiko atau seluruh resiko dari hedger. Spekulator atau di masyarakat banyak digunakan istilah investor melihat pengalihan resiko tersebut berupa celah untuk endapatkan keuntungan, sebagai contoh spekulator atau investor akan menjual kontrak berjangka ketika memiliki spekulasi bahwa harga akan turun, dan akan membeli ketika harga sedang dalam kondisi rendah, atau dengan kata lain spekulan mengambil keuntungan dari fluktuasi harga. ${ }^{20}$ Arbitrator (arbitrage) merupakan orang yang dalam perdagangan berjangka berusaha mengambil keuntungan dari selisih harga yang terdapat dalam dua pasar yang berbeda. Dalam bursa berjangka, fluktuasi harga yang ada dalam pasar spot dapat dipengaruhi oleh berbagai hal seperti kebijakan ekonomi, kondisi geopolitik bahkan oleh hukum permintaan dan penawaran yang ada pada ilmu ekonomi dasar. Akibat dari fluktuasi tersebutlah baik keuntungan dan kerugian dapat di alami oleh

19 Pasal 1 angka 8, Undang-undang Nomor 10 Tahun 2011 tentang Perubahan atas Undang-undang Nomor 32 Tahun 1997 tentang Perdagangan Berjangka Komoditi.

20 Hanafi Sofyan, Perdagangan Berjangka Komoditi dan Ekonomi Indonesia: Tantangan Baru Manajemen Resiko dan Lindung Nilai Bagi Investor Masa Depan (Jakarta: Gramedia Pustaka Utama, 2000), hlm. 85. 
spekulan dalam perdagangan berjangka.

Komoditi yang dapat dijadikan subjek dalam kontrak berjangka dan diperdagangkan dalam bursa berjangka adalah komoditi pertanian, pertambangan (salah satunya adalah emas), kehutanan, industri hulu dan jasa. Masing-masing komoditi yang diperdagangkan tersebut telah ditetapkan secara jelas spesifikasi yang menyangkut jumlah, kualitas dan waktu penyerahannya. Hal tersebut bertujuan agar transaksi berjangka dapat menciptakan kondisi transaksi yang aktif dan likuid.

Emas merupakan salah satu jenis logam mulia yang tergolong dalam komoditi yang paling banyak diminati masyarakat, khususnya sebagai benda penyimpan nilai atau investasi. Emas dapat digunakan sebagai alat pembayaran, standar keuangan, bahkan sebagai cadangan devisa. Harga emas biasanya berbanding lurus dengan tingkat inflasi dan perubahan nilai mata uang(biasanya yang menjadu acuan adalah mata uang Amerika, US dollar). Penggunaan emas sebagai subjek perdagangan komoditi dapat digunakan sebagai sarana lindung nilai karena fluktuasinya cenderung mengikuti nilai mata uang. Kontrak derivatif emas sebagai objek transaksi derivatif melalui sistem perdagangan alternatif diatur dalam Peraturan Kepala Badan Pengawas Perdagangan Berjangka Komoditi Nomor 72/BAPPEBTI/ Per/9/2009.

\section{Pandangan Ekonomi Syariah tentang Transaksi Kontrak Berjangka Emas}

Jual-beli (bai') adalah memberikan sesuatu dengan imbalan sesuatu yang lain. Dalam Islam, jual-beli berarti membalas suatu harta benda dengan harta benda lain yang dikendalikan dengan ijab-qabul menurut cara yang halal atau diperbolehkan. ${ }^{21}$ Dalam fiqh muamalah, jualbeli secara bahasa berarti penukaran sesuatu dengan sesuatu. Dalam madzhab Hanafiah, jual-beli merupakan pertukaran harta dengan harta menggunakan cara tertentu. Harta di sini diartikan sebagai sesuatu yang memiliki manfaat serta ada kecenderungan manusia

21 Abubakar, Kifayatul Akhyar Fii Halli Ghayatil Ikhtisar, hlm. 534. 
untuk menggunakannya dengan suatu cara tertentu yang disebut dengan sighat atau ungkapan Ijab qabul. ${ }^{22}$ Dari pengertiannya ini, ada empat unsur dalam jual-beli, yaitu adanya dua orang atau lebih yang melakukan tukar-menukar; tukar-menukar tersebut berupa barang atau hal yang dikategorikan sebagai harta yang seimbang nilainya; adanya perpindahan kepemilikan; dan dilakukan dengan cara tertentu yang dibenarkan oleh syariat Islam.

Dalam Islam, jual-beli merupakan perbuatan hukum yang diperbolehkan. Dalam Al-Qur’an disebutkan “...Allah telah menghalalkan jual-beli dan mengharamkan riba...”. ${ }^{23}$ Ini berarti, jual-beli merupakan suatu perbuatan yang halal, dan akan berubah menjadi haram dan karenanya dilarang ketika mengandung unsur riba. Demikian juga dalam Hadits Nabi Muhammad SAW disebutkan, "Dari Rif'ah Ibn Rafi, sesungguhnya Rasulullah pernah ditanya 'usaha apa yang paling baik?', Rasulullah SAW menjawab 'Usaha seseorang dengan tangannya sendiri dan setiap jual-beli yang mabrur (jujur)'”, ${ }^{24}$ Dalam Hadits lain, Rasulullah SAW bersabda telah melarang jualbeli dengan spekulasi dan jual-beli gharar.

Berdasarkan nash Al-Qur'an dan Hadits Nabi, maka diketahui bahwa jual-beli yang baik adalah yang berlandaskan transparansi, kejujuran, dan tanpa adanya spekulasi sesuatu yang tidak jelas. Dalam jual-beli harus terbebas dari maysir, gharar, haram, riba dan bathil. Di dalam Islam ditegaskan bahwa dalam setiap jual-beli ada hal-hal yang menjadi koridor dalam melakukan transaksi. Koridor tersebut menjadi batasan apakah suatu transaksi dikatakan sah atau tidak secara syariat Islam. Koridor tersebut adalah maisir, gharar, haram, riba, dan bathil. ${ }^{25}$

Maisir secara harfiah berarti memperoleh sesuatu tanpa bekerja, atau dikaitkan dengan fenomena dimasyarakat ialah perjudian. Gharar merupakan transaksi yang tidak memiliki kejelasan dalam

22 Dimyaudin Djuwaini, Pengantar Fiqih Muamalah (Yogyakarta: Pustaka Pelajar, 2008), hlm. 69.

23 Al-Qur'an, Surat al-Baqarah, ayat 275.

24 Muhammad Ibn Isma'il al-Kahlany al-San'any, Subul al-Salam, Juz III (Bandung: Maktabah Dahlan, tanpa tahun), hlm. 4.

25 Latif Azharudin, Fiqh Muamalah (Ciputat: UIN Jakarta Press, 2005), hlm. 5. 
objek transaksinya. Secara umum gharar dapat dijabarkan sebagai objek transaksi yang tidak jelas wujudnya; objek transaksi yang tidak jelas bisa atau tidak penyerahannya; dan akad dalam transaksi yang tidak jelas baik dari segi waktu ataupun cara pembayarannya. Haram adalah objek yang diperjualbelikan merupakan barang yang secara implisit maupun eksplisit dilarang oleh syariat Islam, seperti minuman keras atau barang curian. Riba adalah pertambahan nilai karena hal yang tidak jelas asal usulnya, atau pertambahan khusus yang dimiliki oleh salah satu pihak tanpa adanya imbalan tertentu. Bathil adalah sesuatu yang dzalim atau bersifat membuat kerugian atau sengsara orang lain baik melalui cara berdagang maupun objek yang diperjualbelikan, baik secara terang-terangan ataupun diam-diam. Suatu transakasi harus dilaksanakan berdasarkan kerelaan masingmasing pihak dan adil sesuai takarannya.

Ijma ulama sepakat bahwa kebutuhan manusia yang sering berhubungan dengan segala sesuatu yang ada dalam kepemilikan orang lain, maka kepemilikan tersebut tidak semata-mata dapat diberikan begitu saja tanpa adanya kompensasi. Jual-beli dalam hal ini merupakan suatu cara dalam mewujudkan pemenuhan kebutuhan manusia, karena pada dasarnya manusia merupakan makhluk sosial yang tidak dapat hidup tanpa bantuan orang lain. ${ }^{26}$

Imam Nawawi dalam syarah al-Muhadzab menjelaskan dalam rukun dalam jual-beli harus meliputi tiga hal, yaitu akid, ma' qud alaihi, dan sighat yang terdiri atas ijab dan qabul. Akid merupakan pihakpihak yang melakukan jual-beli, baik pemilik asli maupun orang yang menjadi wali dari pemilik asli (hukum positif mengenalnya sebagai bezitter), dan memiliki hak untuk mentransaksikannya. ${ }^{27} \mathrm{Ma}$ 'qud alaihi merupakan objek akad yang harus jelas secara bentuk, kadar dan sifatnya, serta diketahui dengan jelas oleh penjual dan pembeli; sehingga melakukan jual-beli barang yang samar, tidak dilihat oleh penjual dan pembeli atau salah satu dari mereka, merupakan jualbeli yang tidak sah. ${ }^{28}$ Sighat (ijab-qabul) merupakan perkataan dari

26 Djuwaini, Pengantar Fiqih Muamalah, hlm. 73.

27 Djuwaini, Pengantar Fiqih Muamalah, hlm. 56.

28 Abubakar, Kifayatul Akhyar Fii Halli Ghayatil Ikhtisar, hlm. 537. 
penjual yang mengisyaratkan penjual menjual benda dengan harga yang dikehendakinya, sedangkan qabul merupakan perkataan pembeli yang menerima penjualan benda oleh penjual dengan harga yang dikehendaki penjual. Ijab dan qabul tidak dapat dilakukan dalam rentang waktu yang lama, sebab jika dilakukan secara terpisah dalam artian ada tenggang waktu maka dapat mengakibatkan batalnya perjanjian jual-beli tersebut. ${ }^{29}$

Dalam penjelasan sebelumnya diketahui bahwa dalam transaksi ekonomi secara konvensional berlaku transaksi berjangka maupun option. Objek transaksinya bervariasi, bisa berupa barang komoditi, surat berharga, maupun valuta asing (valas). Dalam Islam sebenarnya terdapat beberapa jenis transaksi yang relevan dengan atau mirip dengan transaksi berjangka emas. Transaksi tersebut di antaranya adalah: akad salam, akad istisna, dan transaksi khiyar sharat. Akad salam secara etimologis berarti mendahului pembayaran dan mengakhirkan penyerahan barang, atau dengan kata lain menjual sesuatu yang ciri-cirinya disebutkan secara jelas dengan pembayaran modal terlebih dahulu dan barangnya diserahkan di kemudian hari. ${ }^{30}$ Syarat dan rukun dalam salam berupa jenis, mutu, dan jumlah harus transparan; harga dibayarkan secara tunai; harga harus pasti tidak berfluktuasi; dan jangka waktu yang disepakati.

Cara kerja dalam jual-beli dengan akad salam sesungguhnya identik dengan kontrak berjangka emas. Hal ini diarenakan dalam kontrak ini ketika pembeli membeli barang dan dijanjikan akan dilakukan penyerahan sejumlah produk kontrak berjangka khususnya komoditi yang telah disepakati sebelumnya, dan bisa diasumsikan bahwa harga pada akadsalam adalah harga hariini. Namunjika ditelisik lebih jauh terdapat dua faktor yang mengakibatkan harga dalam akad salam akan lebih rendah dari harga hari ini, yaitu, pertama, dalam akad salam modal pembeli harus langsung dibayarkan secara lunas, yang menimbulkan resiko bagi pembeli jika penjual wanprestasi. Hal ini bertolak belakang dengan kontrak berjangka emas yang tidak

29 Abubakar, Kifayatul Akhyar Fii Halli Ghayatil Ikhtisar, hlm. 535.

30 M. Ali Hasan, Berbagai Macam Transaksi dalam Islam (Fiqh Muamalat) (Jakarta: PT. Raja Grafindo Persada, 2003), hlm. 143. 
akan melakukan pembayaran sampai kontraknya selesai. Kedua, adanya cheapest to deliver, yaitu penyerahan termurah. Maksud dari penyerahan termurah adalah saat jatuh tempo penjual pada kontrak salam biasanya memilih salah satu dari komoditas yang memiliki kualitas terbatas yang termurah untuk dilakukan penyerahan. ${ }^{31}$ Kedua faktor ini menggambarkan kurangnya fleksibilitas dari akad salam dibanding kontrak berjangka emas sehingga menimbulkan ketidakpastian bagi pembeli.

Akad istisna merupakan akad dengan cara melakukan pemesanan terhadap barang atau komoditas kepada suatu produsen untuk pembeli atau pemesan. ${ }^{32}$ Akad ini merupakan akad jual-beli yang barangnya masih belum tersedia atau sedang dalam masa produksi dengan spesifikasi barang dan harga yang sudah ditentukan sebelumnya berdasarkan kesepakatan, dan pembayaran dapat dilakukan secara tunai maupun cicil. ${ }^{33}$

Akad istisna sesungguhnya memiliki kemiripan dengan akad salam dalam hal syarat-srayat yang harus dipenuhi, namun berbeda dalam hal metode pembayarannya. Dalam istisna, pembayaran dapat dilakukan dengan cara cicilan dan komoditas yang menjadi objek dapat berupa objek yang masih dalam proses produksi. Kekurangan dalam akad istisna adalah fleksibilitas penjual yang tidak dapat melakukan penjualan kepada pihak lain yang menawarkan harga kepada penjual terhadap produk yang sedang diproduksinya, walaupun sebenarnya penjual ini sudah mendapatkan margin dari tafsiran harga untuk produknya di masa yang akan datang. ${ }^{34}$

Transaksi khiyar sharat secara terminologis adalah pilihan atau mencari yang terbaik di dalam pilihan tersebut, yaitu untuk meneruskan atau untuk membatalkannya. Dari terminologi ini dapat

31 Frank E. Vogel \& Samuel L. Hayes, Islamic Law and Finance (The Netherlands: Kluwer Law International, 1998), hlm. 265.

32 Ascarya, Akad dan Produk Bank Syariah (Jakarta: PT. Rajawali Pers, 2008), hlm. 96.

33 Irma Devita Purnamasari dan Suswinarto, Panduan Lengkap Hukum Praktis Populer Kiat-Kiat Cerdas, Mudah, dan Bijak Memahami Masalah Akad Syariah (Bandung: PT Mizan Pustaka, 2001), hlm. 70.

34 Vogel \& Hayes, Islamic Law and Finance, hlm. 267. 
dikatakan bahwa khiyar merupakan bentuk dari pengakhiran akad. Berakhirnya akad di dalam bentuk khiyar dilakukan dalam sebuah perjanjian di awal akad. Namun khiyar merupakan hak yang telah melakat di dalam akad walaupun tidak dinyatakan. ${ }^{35}$

Terdapat dua jenis khiyar, yaitu khiyar majelis dan khiyar sharat. Khiyar Majelis merupakan khiyar yang ditetapkan oleh para pihak, namun dengan catatan selama para pihak masih berada di dalam tempat transaksi. ${ }^{36}$ Khiyar sharat berlaku ketika belum adanya pembayaran maupun penyerahan barang, sehingga khiyar tidak bisa dilakukan jika pembayaran atau penyerahan barang sudah dilakukan. Akad khiyar tidak dapat disamakan dengan transaksi berjangka emas, karena khiyar menjadi tidak berlaku ketika penyerahaan barang atau pembayaran sudah terjadi.

Uraian sebelumnya menyebutkan bahwa Islam menghalalkan jual-beli komoditas baik secara tunai maupun tangguh. ${ }^{37}$ Saham perusahaan atau obligasi dapat dianalogikan layaknya komoditi karena sejatinya saham suatu perusahaan ataupun obligasi tidak dapat dianggap sebagai uang yang merupakan alat tukar pembayaran atas segala barang. Namun Islam tidak memperbolehkan jual-beli hutang dengan hutang guna menghindari transaksi dari barang yang belum dimiliki. Dalam Islam, pembayaran dapat dilakukan walaupun barang yang menjadi objek transaksi belum ada dengan catatan transaksi jual-beli tersebut menggunakan akad salam. Hal yang sama juga berlaku bagi transaksi yang menggunakan akad murabahah, walaupun penyerahan barang dilakukan terlebih dahulu dan uang dibayarkan belakangan. Adapun dalam akad istisna, walaupun harga ditangguhkan, namun pada hakikatnya barang yang menjadi objek transaksi tersebut sudah ada dan kepemilikannya ada pada penjual dan barang sedang dalam proses pembuatan yang sesuai dengan spesifikasi yang diinginkan pembeli. Dengan demikian, unsur yang

35 Ridwan Nurdin, Fiqh Muamalah (Sejarah, Hukum, dan Perkembangannya) (Banda Aceh: Yayasan PeNA, 2010), hlm. 60.

36 Wahbah Zuhaili, Al-Fiqhu As-Syafi"i Al-Muyassar, terj. Muhammad Afifidan Abdul Hafiz (Jakarta: Almahira, 2010), hlm. 676.

37 Istilah bay' al-kali' bi al-kali', yaitu jual-beli barang secara tangguh, baik dalam penyerahan harga maupun barangnya. 
harus dipenuhi dalam jual-beli adalah thaman (uang, harga) dan muthaman (barang). Walaupun dari kedua unsur tersebut hanya satu yang dipenuhi, tetap terjadi jual-beli dengan catatan sesuai dengan kondisi yang dijelaskan sebelumnya.

Jual-beli option sesungguhnya memiliki kemiripan dengan jualbeli melalui akad khiyar sharat. Objek transaksi dalam khiyar sharat adalah barang komoditi atau barang tersebut memiliki kejelasan secara kepemilikan ataupun keberadaannya, sedangkan dalam jualbeli option, yang diperjualbelikan adalah kontraknya dan bukan barangnya..$^{38}$ Barang dalam hal ini hanya dijadikan sebagai acuan harga kontrak tersebut, sedangkan keberadaan dan kepemilikannya belum memiliki kejelasan. Dalam Islam, transaksi berjangka emas derivatif, baik secara future atau forward, tidak diperbolehkan karena komoditas yang dimaksud belum dimiliki oleh penjual sebagaimana yang banyak terjadi di pasar sekunder. Jual-beli atas komoditas sebelum adanya kepemilikan tersebut pada dasarnya mengacu pada spekulasi untuk mencari keuntungan dalam jangka pendek, dan spekulator hanya mencari capital gain dari transaksi mereka sehingga transaksi yang dilakukan tidak mencerminkan kehidupan transaksi secara riil. Hal tersebut merupakan salah satu bentuk dari untunguntungan atau gambling (maysir, qimar) yang merupakan sesuatu yang dilarang dalam Islam.

Seperti yang sudah dijelaskan sebelumnya kontrak berjangka emas merupakan suatu sarana untuk melindungi nilai atau hedging yang diakbitkan oleh fluktuasi harga karena berbagai hal. Lindung nilai dengan menggunakan kontrak berjangka emas merupakan lindung nilai yang resikonya dialihkan oleh satu pihak ke pihak lainnya. Karena kontrak berjangka emas diperdagangkan dengan sistem zero-sum, maka ia merupakan bentuk dari aktivitas transfer resiko. ${ }^{39}$

Dalam Islam, mitigasi resiko harusnya dikelola secara bersama antara pihak pedagang maupun pembeli. Dalam transaksi berjangka

38 Christopher Pass, dkk., Kamus Lengkap Ekonomi, hlm. 256.

39 Bambang Tutuko, "Perdagangan Berjangka Komoditi: Berdzikirlah dengan Physical Delivery”, Eldinar: Jurnal Keuangan \& Perbankan Syariah, 5, 2 (2017), hlm. 45. 
emas, kedua belah pihak sama-sama menanggung resiko dari fluktuasi harga, namun dengan sistematika jika terjadinya suatu resiko kepada pembeli, maka pihak pedagang yang menanggungnya. Begitu pula sebaliknya, jika terjadi resiko pada pedangang, maka pembeli yang harus menanggungnya. Berangkat dari hal tersebut kontrak berjangka emas dibuat dengan spesifikasi yang memungkinkan para pihaknya untuk melikuidasi posisinya setiap saat dan pada posisi harga berapa pun (melalui online trading) tanpa melihat proses serah terima fisik dari barang yang bersangkutan, sehingga menimbulkan ketidakpastian akan harga dan proses serah terima. Kondisi ini tentu tidak sesuai dengan ketentuan Al-Qur'an, yaitu larangan memakan harta sesama umat manusia dengan jalan yang batil dan perlunya prinsip suka sama-suka dalam perniagaan. ${ }^{40}$

Oleh karena itu, lindung nilai yang menjadi pokok utama dalam transakasi berjangka emas seharusnya dilakukan dengan prinsip saling menguntungkan (suka sama suka) antara pihak penjual dan pembeli. Mekanisme yang berlangsung pada transaksi berjangka masih bisa merugikan salah satu pihak, sehingga tidak sejalan dengan prinsip ekonomi syariah.

Kontrak berjangka emas juga dilakukan dengan cara menggunakan uang jaminan (margin ${ }^{41}$ sehingga memberikan kesempatan kepada pelaku pasar untuk melakukan penjualan kontrak berjangka emas tanpa harus memiliki komoditinya terlebih dahulu jika dilakukan secara short selling.42 Dalam hal ini sudah sangat jelas melanggar prinsip jual-beli dalam Islam, di mana seseorang baru dapat menjual barangnya jika sudah menerima dari pihak penjual

40 Al-Qur.an, urat An-Nisa ayat 29, "Hai orang-orang yang beriman, janganlah kamu saling memakan harta sesamamu dengan jalan yang batil, kecuali dengan jalan perniagaan yang berlaku dengan suka sama-suka di antara kamu”.

41 Pasal 1 butir 7 Peraturan Kepala Badan Pengawas Perdagangan Berjangka Komoditi Nomor 117/BAPPEBTI/PER/03/2015 tentang Penempatan Margin Untuk Melaksanakan Transaksi di Bidang Perdagangan Berjangka Komoditi.

42 Transaksi short selling dikenal di dalam transaksi efek di mana efek yang dimaksud tidak dimiliki oleh penjual efek pada saat transaksi dilaksanakan. 
dan menguasainya, sebagaimana hadits Nabi "Barang siapa membeli bahan makanan, maka janganlah dia menjualnya kembali sebelum menerimanya."

Kontrak berjangka emas yang diperdagangangkan dengan menggunakan margin menjadikan instrumen tersebut digunakan untuk sarana berspekulasi guna mendapat keuntungan dari fluktuasi harga. Hal ini karena berdagang menggunakan uang jaminan akan memberikan faktor kelipatan tinggi (high leverage ${ }^{43}$ bagi pembeli dan penjual dalam mendapat keuntungan ketimbang berjualan emas secara konvensional ataupun secara fisik. Adanya high leverage inilah yang menyebabkan transaksi kontrak berjangka emas sangat kental dengan praktik spekulasi. Dalam Islam, spekulasi sangat identik dengan judi atau maysir, dan karenanya dilarang. ${ }^{44}$

Dari pemaparan di atas, diketahui bahwa transaksi berjangka komoditas emas secara konvensional merupakan transaksi yang tidak sejalan dengan prinsip dalam ekonomi syariah. Indonesia sejatinya telah mengatur terkait transaksi berjangka komoditas emas secara syariah melalui Fatwa Dewan Syariah Nasional Majelis Ulama Indonesia Nomor 82 Tahun 2011 tentang Perdagangan Berjangka Komoditi Berdasarkan Prinsip Syariah di Bursa Komoditi. Adanya Fatwa DSN MUI ini memberikan alternatif pilihan transaksi berjangka syariah untuk melakukan transaksi yang sesuai dengan syariat Islam, sehingga investor terlepas dari jerat maysir, gharar, riba, haram dan bathil. Dalam Fatwa DSN MUI disebutkan, akad yang tepat untuk melakukan transaksi berjangka komoditas emas adalah akad murabahah. ${ }^{45}$ Namun, untuk dapat berlangsung tentu saja butuh persetujuan dari pihak pelaksana terkait seperti Badan Pengawas

43 High leverage adalah keadaan di mana dari penempatan dana yang cukup tinggi dapat diperoleh keuntungan berupa penambahan dana atau kerugian yang cukup tinggi akibat perubahan harga komoditi yang terjadi sesuai penempatan nilai dana yang di tempatkan.

44 QS. Al-Maidah ayat 90: "Hai orang-orang yang beriman, sesungguhnya (meminum) khamar, berjudi, (berkorban untuk) berhala, mengundi nasib dengan panah, adalah termasuk perbuatan syaitan. Maka jauhilah perbuatan-perbuatan itu agar kamu mendapat keberuntungan”.

45 Ketentuan dalam Fatwa DSN-MUI No.82 Tahun 2011 tentang Perdagangan Komoditi berdasarkan Prinsip Syariah bagian 1-7. 
Perdagangan Berjangka Komoditi (BAPPEBTI) dan kesiapan dari Bursa Berjangka untuk menyediakan produk berjangka emas syariah.

Fatwa DSN MUI Nomor 82 Tahun 2011 menjelaskan bahwa pihak-pihak yang ikut terlibat dalam transaksi derivatif syariah adalah:

1. Peserta perdagangan komoditi yaitu produsen, prosesor (pengolah), pedagang (exportir, pengumpul dan importir);

2. Peserta komersial (Lembaga Keuangan Syariah) yaitu Bank Syariah (BUS dan BPRS) dan modal Ventura Syariah;

3. Peserta Agen (Bank Syariah atau lembaga keuangan non bank) yaitu pihak yang melaksanakan amanat peserta pedagang komoditi atau melaksanakan amanat peserta komersial;

4. Konsumen Komoditi, yaitu institusi (bank syariah atau perusahaan), dan individu (perorangan);

5. Jakarta Futures Exchange (JFX) selaku bursa berjangka.

Dari skema transaksi diketahui hal yang sangat kontras adalah pihak konsumen komoditi dapat memilih penyerahan komoditi secara fisik. Secara singkat skema atau prosedur transaksi derivatif syariah adalah seperti berikut. Pertama, konsumen komoditi mendatangi peserta komersial untuk melakukan pesanan pembelian suatu komoditi yang termasuk di dalamnya emas. Mengacu pada permintaan tersebut, peserta komersial membeli komoditi berdasarkan transaksi dengan pembayaran tunai dari semua peserta pedagang komoditi untuk komoditi spesifik yang akan ditransaksikan hingga kepemilikan komoditi akan beralih dari peserta pedagang komoditi kepada peserta komersial dengan ditandai oleh penerbitan Surat Penguasaan atas Komoditi Tersetujui (SPAKT) oleh Bursa.

Peserta Komersial melakukan pembayaran secara tunai terhadap transaksasi tersebut dengan melalui rekenikng khusus bursa untuk transaksi komoditi syariah yang disediakan oleh peserta komersial. Setelah mendapat penguasaan terhadap komoditi tersebut melalui SPAKT, peserta komersial dapat menjuak komoditi kepada konsumen komoditi dengan akad Murabahah, sehingga SPKAT baru dapat diterbitkan oleh bursa dengan mencantumkan nilai awal dengan 
peserta komersial berdasarkan nilai transaksi yang terjadi antara keduanya. Kepemilikan akan komoditi tersebut terlah beralih dengan terbitnya SPKAT baru, dengan mengacu kepada akad murabahah, maka pembayaran yang dilakukan oleh konsumen komoditi kepada peserta komersial dilakukan secara tangguh.

Di atas adalah skema jika konsumen komoditi tidak ingin menerima penyerahan secara fisik yaitu hanya melalui SPAKT. Jika konsumen komoditi ingin menerima penyerahan secara fisik, konsumen komoditi akan menerima dokumen serah terima dari Peserta Pedagang Komoditi, bursa akan memantau proses dari serah terima tersebut lalu bursa akan melakukan pembayaran kepada peserta pedagang komoditi. Namun apabila konsumen komoditi mengambil keputusan dengan ingin menjual kembali komoditi terkait di bursa, bursa akan membeli komoditi dari konsumen komoditi dan melakukan pembayaran secara tunai mewakili peserta pedagang berdasarkan akad wakalah. Pada saat bursa melakukan pembelian dengan mewakili peserta pedagang komoditi, komoditi yang diterima oleh masing-masing pedagang komoditi akan berasal dari pedagang komoditi yang lain secara acak guna menghindari pembelian kembali komoditi yang dijualnya di awal perdagangan. Berdasarkan penjelasan tersebut dapat dipahami bahwa dalam hal ini bursa harus melakukan melakukan penyerahan secara fisik yang sesuai dengan pesanan pembeli.

\section{Kesimpulan}

Islam tidak melarang siapa pun melakukan kesepakatan transaksi jualbeli dengan pihak yang dikehendakinya dalam bentuk apapun selama didasari itikad dan niat yang baik dan tidak dikategorikan jual-beli yang dilarang (maisir, gharar, haram, riba dan bathil). Dalam jual-beli, unsur spekulasi merupakan sesuatu yang terkadang tidak dapat dipisahkan, dan dalam Islam, spekulasi yang dilarang adalah spekulasi yang dilakukan tanpa kerja keras dalam hal yang riil, bukan hanya sekadar permainan untung dan rugi. Transaksi emas berjangka sangkat kental kaitannya dengan transaksi yang bersifat spekulatif. Dalam 
perspektif hukum ekonomi Islam, transaksi tersebut mengandung unsur maisir dan gharar, sehingga termasuk yang dilarang. Pelarangan tersebut disebabkan objek transaksinya berupa hal yang tidak jelas (majhul), baik keberadaan maupun penyerahan. Transaksi berjangka emas dalam bursa berjangka bukanlah jual-beli secara sungguhan, karena di dalamnnya tidak terdapat unsur serah-terima antara kedua belah pihak yang melakukan transaksi; padahal salah satu syarat dari jual-beli harus adanya penyerahan objek transaksi dan pembayaran.

Kontrak berjangka emas yang menggunakan akad murabahah tidak jauh berbeda dengan kontrak berjangka emas secara konvensional yang berada di bursa. Pembedanya adalah pihak investor atau konsumen komoditi dapat menerima komoditi secara fisik, namun yang perlu dikaji lebih lanjut adalah bagaimana dengan kondisi baik secara kualitas maupun kuantitas jika transaksi dilakukan secara online trading.

\section{Daftar Pustaka}

\section{Artikel/Buku/Laporan}

Abod, Sheikh Ghazali Shaikh, dkk. An Introduction to Islamic Finance. Kuala Lumpur: Quill Publishers, 1992.

Abubakar, Taqiyyudin bin Muhammad. Kifayatul Akhyar fii Halli Ghayatil Ikhtisar, alih bahasa Syarifudin Anwar dan Misbah Mustofa. Surabaya: CV Bina Iman, 1995.

'Adhim, Hamdi Abdul. Al-Ta'amul fi Aswaq al-'Umulat al-Dawliyah.

Kairo: International Institute for Islamic Thougt, 1996.

Al-San'any, Muhammad Ibn Isma'il al-Kahlany. Subul al-Salam, Juz III. Bandung: Maktabah Dahlan, tanpa tahun.

Ascarya. Akad dan Produk Bank Syariah. Jakarta: PT. Rajawali Pers, 2008.

Azharudin, Latif. Fiqh Muamalah. Ciputat: UIN Jakarta Press, 2005. Buchori, Imam. "Transaksi Derivatif dalam Perspektif Hukum Islam”. Al-Q̄̄nūn, 12, 2 (2009): 130-154.

Dimyati. "Transaksi Derivatif dalam Perspektif Ekonomi Syariah". Irtifaq, 2, 1 (2015): 98-115. 
Djuwaini, Dimyaudin. Pengantar Fiqih Muamalah. Yogyakarta: Pustaka Pelajar, 2008.

Fafozzi, FrankJ. Pasar dan Lembaga Keuangan. Jakarta: Salemba Empat, 1999.

Hasan, M. Ali. Berbagai Macam Transaksi dalam Islam (Fiqh Muamalat). Jakarta: PT. Raja Grafindo Persada, 2003.

Hull, John C. Options, Futures and Other Derivatives. New Jersey: Prentice-Hall,1997.

Martin, John D. Dasar-Dasar Manjemen Keuangan. Terjemah oleh Haris Munandar. Jakarta: Raja Grafindo Persada, 1994.

Morris, Virginia B. dan Kenneth B. Morris. Dictionary of Financial Terms. New York: Lightbulb Press, tanpa tahun.

Muslich, Ahmad Wardi. Fiqh Muamalat: Akad Jual-beli (Kifayatul alAkhyar Juz I). Surabaya: Darul Ilmi, 2010.

Nurdin, Ridwan. FiqhMuamalah:Sejarah, Hukum, danPerkembangannya. Banda Aceh: Yayasan PeNA, 2010.

Pass, Christopher, Bryan Lowes, dan Leslie Davis. Kamus Lengkap Ekonomi. Terjemah oleh Tumpal Rumapea. Jakarta: Penerbit Erlangga, 1998.

Purnamasari, Irma Devita dan Suswinarto. Panduan Lengkap Hukum Praktis Populer Kiat-Kiat Cerdas, Mudah, dan Bijak Memahami Masalah Akad Syariah. Bandung: PT Mizan Pustaka, 2001.

Rae, Dian Ediana. Transaksi Derivatif dan Masalah Regulasidi Indonesia. Jakarta: PT Elex Media Komputindo, 2008.

Salim, Lani. Derivatif: Option dan Varrant. Jakarta: Gramedia, 2003.

Sofyan, Hanafi. Perdagangan Berjangka Komoditi dan Ekonomi Indonesia:

Tantangan Baru Manajemen Risiko dan Lindung Nilai Bagi Investor Masa Depan. Jakarta: Gramedia Pustaka Utama, 2000.

Tutuko, Bambang. "Perdagangan Berjangka Komoditi: Berdzikirlah dengan Physical Delivery". Eldinar: Jurnal Keuangan \& Perbankan Syariah, 5, 2 (2017): 44-65. DOI: 10.18860/ed.v5i2.5239

Vogel, Frank E. dan Samuel L. Hayes. Islamic Law and Finance. The Netherlands: Kluwer Law International, 1998.

Zuhaili, Wahbah. Al-Fiqhu As-Syafi"i Al-Muyassar. Terjemah oleh Muhammad Afifi dan Abdul Hafiz. Jakarta: Almahira, 2010. 


\section{Peraturan Hukum}

Republik Indonesia. Undang-undang Nomor 10 Tahun 2011 tentang Perubahan atas Undang-undang Nomor 32 Tahun 1997 tentang Perdagangan Berjangka Komoditi.

Republik Indonesia, Badan Pengawas Perdagangan Berjangka dan Komoditi. Peraturan Kepala Nomor 72 / BAPPEBTI/ Per/ 9/ 2009 tentang Kontrak Derivatif Yang diperdagangkan Dalam Pasar Sekunder.

Republik Indonesia, Badan Pengawas Perdagangan Berjangka dan Komoditi. Peraturan Kepala Nomor 117/BAPPEBTI/ PER/03/2015 tentang Penempatan MarginUntukMelaksanakan Transaksi di Bidang Perdagangan Berjangka Komoditi.

Republik Indonesia, Bank Indonesia. Peraturan No. 7/31/PBI/2008 tentang Transaksi Derivatif.

Republik Indonesia, Majelis Ulama Indonesia. Fatwa DSN-MUI Nomor 82 Tahun 2011 tentang Perdagangan Komoditi. 